\title{
Segment Reporting Level And Analyst Forecast Accuracy
}

Kyongsun Heo, Kangnam University, South Korea

Seoyoung Doo, Korean Institute of Certified Public Accountants, South Korea

\begin{abstract}
In a setting where the primary financial statements have been converted from individual financial statements to consolidated financial statements in Korea, we examine the effect of segment information disclosed by the firm on analysts' consolidated-base earnings forecast accuracy. Since Korean firms have prepared the primary financial statements on a non-consolidated basis in the pre-IFRS regime, the adoption of International Financial Reporting Standards (IFRS) leads to a great deal of difficulties and complexities in making accurate consolidated forecasts for users of financial statements, even for financial analysts who are sophisticated users of financial statements. In this situation, we conjecture that the amount of details and types of information in segment disclosure will influence analysts' forecast accuracy. Consistent with the prediction, we find that financial analysts are able to make more accurate earnings projections when firms provide more disaggregated accounting figures by each segment. Moreover, we find that analysts can make forecasts more accurately when firms disclose more persistent earnings component (i.e., segment operating income). Furthermore, we find that the effect of the segment disclosure levels on analysts' forecast accuracy is more pronounced for firms with multi-segments. Our results indicate that disaggregated segment information is a useful source for financial analysts to have better understanding about complete picture of firms' consolidated earnings and improve their forecasting performance.
\end{abstract}

Keywords: IFRS; Segment Reporting; Consolidated Financial Statements; Analyst Forecast Accuracy

\section{INTRODUCTION}

$\mathscr{I}$ n 2011, South Korea introduced International Financial Reporting Standards (IFRS) to better align with globally accepted financial reporting standards and to enhance accounting transparency of all listed firms. The Korean adoption of IFRS leads to a transition of primary financial statements from non-consolidated statements to consolidated statements. ${ }^{1}$ A Firm which controls one or more other firms should disclose a set of consolidated financial statements as the primary financial statements by combining the financial results of subsidiaries with its own financial statements. With the move to consolidated-base disclosure in the post-IFRS, financial statements users, even sophisticated financial analysts, experience difficulties in understanding the individual financial results of all subsidiaries and further reflecting those performances accurately into consolidated forecasts. In these situations, we examine whether the amount of details and types of segment information disclosed in the notes to the financial statements are useful to aid financial analysts in forecasting consolidated earnings of a parent firm.

There has been constant debate in the U.S. as to how useful the segment reporting is to investors. Some prior studies argue that segment disclosure facilitate investors' predictions of future earnings in U.S. setting (Kochanek, 1974; Collins, 1976; Baldwin, 1984). However, others criticize that segment reporting does not contain useful information and rather reduces comparability across firms because accounting standards allow management to exercise greater discretions in determining reportable segments. Specifically, under IFRS 8 'Operating Segments', managers can define reportable segments for external reporting to be consistent with their internal organizational structure and reporting system.

\footnotetext{
${ }^{1}$ In Europe, consolidated financial statements were the primary financial statements before the introduction of IFRS. In Korea, however, individual financial statements have been prepared as the primary financial statements in accordance with the Korean Generally Accepted Accounting Principles (K-GAAP) in the pre-IFRS period.
} 
While the management approach results in a wide variation of segment disclosure levels across firms, prior studies exclusively focus on the usefulness of numbers of reportable segments. A few studies investigate the effect of disaggregated accounting figures by each segment on financial statements users. Segment financial information enables users to evaluate the financial effects of business activities in which firms engage and to understand the economic environments in which firms operate. Thus, in a setting where even financial analysts with expertise and knowledge in firms' financial performance have difficulties in forecasting consolidated financial numbers under IFRS, we postulate that segment information is utilized as an important source for financial analysts to have a better understanding of complete picture of firms' earnings and improve their forecasting performance.

We predict that financial analysts are able to make more accurate earnings projections when firms provide more disaggregated accounting figures by each segment. Prior studies present that segmental information facilitate investors and analysts' predictions of future performance (Kochanek, 1974; Baldwin, 1984; Ettredge, Kwon, Smith, \& Zarowin, 2005; Berger \& Hann, 2003). We extend prior literature by focusing on the impact of the details of segment reporting on financial statements users' decision making. In addition, we expect that analysts can forecast net income more accurately when firms disclose segment operating income. Furthermore, we predict that the beneficial effect of the segment disclosure on analyst's forecast accuracy is more pronounced when analysts predict earnings for firms with the greater degree of business diversification (multi-segment).

As a proxy for segment disclosure level, we utilize both the number of detailed accounting information and the types of information for each identified operating segment reported in the footnotes to financial statements. To the extent that firms have some latitude in determining the level of disaggregated accounting figures by each segment for external reporting, they can set the number of accounting information by each business segment (SEGDIS) and by each geographical segment (GDIS). In addition, firms can determine whether they disclose the segment operating income (SDIS_OI).

We use footnote information of the annual reports to collect the firm's segment disclosure data. Our sample consists of consolidated earnings forecasts of individual financial analysts who follow firms listed in Korean Stock Exchange. Sample period is over the period from 2011 to 2015 in the post-IFRS era. We find that the more disaggregated accounting information about each segment firms disclose in their annual reports, the more accurate consolidated earnings financial analysts can make. Besides, we find that segment-level disclosure of more persistent earnings component, operating income, is positively related to analysts' forecast accuracy of consolidated net income suggesting that disclosure of more persistent accounting information by each segment facilitates analysts' forecasts of consolidated earnings. Lastly, we find that segment information is more beneficial to analysts who follow multisegment firms.

Our paper contributes to the existing literature as follows. First, while prior studies focus on the opportunistic use of managerial discretions regarding the extent of reported segments, we analyze how useful the details and the types of accounting information for each segment that firms release in their annual reports is. Thus, we show that the degree of segment disclosure levels on the basis of the amount of voluntary disaggregated accounts influence the predictive ability of financial analysts for future consolidated earnings.

Second, we contribute to IFRS studies by examining the role of segment disclosure information to external users. As principle-based IFRS results in differences in the scope of disclosure among companies, it is of interest for investors and managers to investigate whether cross-sectional differences in disclosure levels in public information among firms influence the differences in analysts' forecast properties. Using a unique research setting where the adoption of IFRS changed corporate financial reporting from an individual basis to a consolidated basis, we test the effect of firmprovided information on analysts' forecast properties by measuring the extent of segment-level disclosure.

Third, our study provides insights on whether public information in the notes to financial statements can reduce information asymmetry by enhancing the information quality. Although it is of interest and importance for regulators, scholars, and various other parties to examine differential effect of public disclosure, there is little empirical research on these issues due to difficulties in measuring "disclosure quality". Given the importance of analysts' forecasts, we provide some evidence on whether segment information aids analysts to forecast consolidated earnings accurately. 
The rest of the paper is organized as follows. Section II develops our hypotheses in the context of related research, while Section III contains a brief description of the IFRS 8 'Operating Segments' and describes our empirical proxy of segment disclosure quality. Section IV presents our sample selection procedures and provides methodology to test our hypotheses. Section V presents the results of our analyses. Finally, Section VI provides a brief summary and conclusion.

\section{HYPOTHESES DEVELOPMENT}

\section{Segment Disclosure Levels}

Since firms can determine reportable segments on the basis of internal management report, prior studies show that firms have motives to the opportunistic use of managerial discretion regarding disclosure of segment information (Nichols, Street, \& Tarca, 2013). Berger and Hann (2007) show that managers are likely to withhold information of segments with lower abnormal earnings to avoid intensified external monitoring. In such cases, the discretions on segment reporting can reduce usefulness and comparability of information across firms.

Nevertheless, most academic studies argue that corporate disclosures, including voluntary and mandatory disclosure, have a positively influence on analysts' forecast characteristics (Baginski \& Hassell, 1990; Jennings, 1987). Lang and Lundholm (1996) report that firms with more informative disclosure policies have a larger analysts following, more accurate analysts' earnings forecasts, less dispersion among individual analyst's forecasts.

In this context, we posit that segment information enables users of financial statements to better evaluate the financial effects of the business activities in which firms engage and to understand the economic environments in which firms operate. In general, segment disclosure is considered as an important source of information about the firm's operations and prospects (Nichols et al. 2013). In addition, geographical segment information is utilized as important source for assessing the impact of economic and political conditions on the firm's business (Nichols et al. 2013).

Different from prior studies which focus on the extent of reportable segments, we focus on the number of line items for each segment disclosed in their annual reports as segment reporting levels. The management approach of IFRS 8 allows firms to determine details of segment-line accounting items as well as the extent of reportable segments. For example, some firms disclose more roughly-provided segment accounting numbers, such as segment assets, segment liabilities, and segment revenues from external customers and from internal transactions, while other firms disclose more specific segment information, such as segment interest revenue (expense) and capital expenditures on top of segment assets or liability information in their annual reports.

Segment-based disclosure of various accounting items such as disaggregated earnings or assets is useful to better estimate different rate of growth, profitability, risk and operational efficiency and to predict future business performance of the firm considering the differences by segments (Kinney, 1971; Kochanek, 1974; Nichols et al. 2013). Therefore, we postulate that disaggregated accounting data by each segment provides more complete knowledge of earnings and accounting flow among segments to financial statements users.

In summary, if the firm discloses more detailed accounting information per each segment, financial statements users will be able to better understand reported performance and predict future consolidated performance of the firm. Financial analysts, sophisticated users of financial statements, believe that segment information is useful and use it in their forecasting work (Ettredge et al. 2005). In particular, in a setting where the primary financial statements have been changed from individual financial statements to consolidated financial statements in Korea and financial analysts have difficulties in forecasting consolidated financial numbers under IFRS, we expect that the amount of details in segment disclosure will influence the accuracy of analysts' consolidated earnings forecasts. This leads to the following hypothesis 1:

Hypothesis 1: The accuracy of analysts' earnings forecasts is positively associated with the amount of details in segment disclosure in the annual reports. 


\section{Segment Disclosure Information}

Segment disclosure quality is not only related to the levels of details, but it also related to the types of segment information disclosed in annual reports. Based on surveys of Korean analysts, Chun, Lee, Kim, Kim, \& Cho, (2013) document that current year financial statements are the most key references for analysts to predict next year earnings, and operating income figures in financial statements are one of the most important quantitative sources in their forecasting work. Thus, we predict that firms who disclose more crucial components of earnings by each segment, such as operating income, would enable analysts to make better use of financial information in the process of forecasting future earnings.

In particular, there are systematic differences between "transitory earnings" and "operating earnings" in their importance for predicting earnings. The operating earnings components are more relevant and persistent to predict the next period earnings (Ohlson, 1999). Therefore, we postulate that the disclosure of operating earnings by each segment is crucial to improve usefulness of segment reporting. This leads to the following hypothesis 2 :

Hypothesis 2: The accuracy of analysts' earnings forecasts is positively associated with the disclosure of segment operating income in the annual reports.

\section{Segment Disclosure Level and Multi-Segment Firms}

A multi-segment firm is generally considered as a firm with greater complexity than a single-segment firm. A firm in complexity may easily deliver misleading signals to investors due to the uncertain activities among segments (Shin \& Stulz, 1998; Rajan, Servaes, \& Zingales, 2000; Duchin, 2010; Bonsall \& Miller, 2014). Besides, a multi-segment firm is related with less transparency due to vague earnings flows among internal segments, thus resulting in greater information asymmetry between the firm and external investors. Berger and Hann (2007) illustrates that managers have incentives to withhold information on segments with lower profitability for the concerns that external monitoring will be stronger. It implies that multi-segment firms have an incentive to hold a certain level of information asymmetry to reinforce managers' opportunity to obtain private benefits (Hope \& Thomas, 2008).

We postulate that a higher level of segment disclosure is more useful for financial statements users to predict future earnings when firms are in greater complexity and less transparency. When the firm has greater complexity and less transparency, information asymmetry between the firm and market participants increases. In this case, segment disclosure will provide benefits to reduce information asymmetry between the firm and external users. Thus, we hypothesize that the positive impact of segment disclosure, which improves the accuracy of analysts' forecast, is greater for firms with greater complexity than those with less complexity.

Hypothesis 3: The positive association between the accuracy of analysts' earnings forecasts and the quality of segment disclosure is more pronounced for the firm with more numbers of operating segments.

\section{SEGMENT DISCLOSURE LEVEL}

\subsection{IFRS 8 Operating Segments}

IFRS 8 'Operating Segments' requires firms to disclose segment information to external users, consistent with such an internal reporting system (IFRS 8, para. 5 and 23-27). An operating segment is defined as a component of an entity that engages in business activities from which it may earn revenues and incur expenses (IFRS 8, para. 5). Moreover, IFRS 8 offers for certain segment aggregation criteria based on similarities in the nature of the products and services, the nature of the process of production, the type of customers, and the nature of the regulatory environment and so on. Nevertheless, as IFRS 8 follows 'management approach' considering organizational structure and internal reporting system, managers can choose the number of reportable business and/or geographical segments.

Many prior studies on managerial discretions on segment disclosure focus on discretions regarding the determinations of reportable segments. However, in this paper, we focus on the extent of segment-level information as segment disclosure quality. IFRS 8 provides a general guidance for firms to choose which items of segment information to be 
disclosed. Accordingly, firms' managers have considerable discretion in determining the amount of details of segment information disclosed in the annual report.

Exhibit 1 provides examples of segment disclosures of firms. Panel A shows segment information disclosed in 2011 annual reports of POSCO which is the largest steel company in Korea. In the footnotes of annual reports, the POSCO group divided its operation into four segments: steel, trading, construction, and other business segments and disclosed ten items of accounting information for each segment. Panel B shows segment information of SM which is the representative entertainment management company in Korea. According to the annual reports in 2011, the SM group disclosed recording and entertainment management business as two major business segments and reported only segment revenues by each segment. The group explained that internal data reported to its chief operating decision maker includes only revenue information for each segment and does not include segment profits or losses, segment assets and liabilities. Exhibit 1 suggests that there is wide variation in the range of disaggregated segment information among firms under the IFRS 8 , which is an important motivation for this study.

Exhibit 1. Illustration of Segment Disclosure

Panel A: Segment information in 2011 annual reports of POSCO

POSCO is the largest steel company in Korea. In 2011 annual reports, the POSCO group divided its operation into four segments: steel, trading, construction, and other business segments, depending on the internal reporting system for management decisions. For each segment, the POSCO group disclosed ten items of accounting information.

\begin{tabular}{|l|c|c|c|c|c|c|c|}
\multicolumn{1}{|c|}{ Segments } & Steel & Trade & Const. & Others & $\begin{array}{c}\text { (in ten billions of } K R W \text { ) } \\
\text { Adotal }\end{array}$ \\
\hline Revenues from external customers & 39,152 & 21,097 & 5,476 & 3,213 & - & 68,939 \\
\hline Revenues from internal transactions & 17,139 & 7,526 & 2,997 & 2,446 & - & 30,108 \\
\hline Interest revenue & 155 & 44 & 23 & 22 & -27 & 216 \\
\hline Interest expense & 551 & 94 & 69 & 111 & -36 & 788 \\
\hline Depreciation and amortization & 2,128 & 37 & 31 & 178 & -109 & 2,266 \\
\hline Profit or loss by the equity method & -33 & - & - & -7 & 91 & 51 \\
\hline Income tax expense & 1,112 & 35 & 23 & 16 & -118 & 1,068 \\
\hline Net income & 3,689 & 195 & 155 & 155 & -480 & 3,714 \\
\hline Investments by the equity method & 14,227 & 1,900 & 918 & 186 & $-13,396$ & 3,835 \\
\hline Acquisition of non-current assets & 9,385 & 607 & 208 & 595 & -241 & 10,553 \\
\hline
\end{tabular}

Panel B: Segment information in 2011 annual reports of SM

SM is an entertainment management company in Korea. According to the annual reports in 2011, the SM group engages in recording business and entertainment management business as major business segments. The SM group disclosed only segment revenues by each reportable segment in its annual reports. The group also disclosed that internal data reported to its chief operating decision maker includes only revenue information for each segment and does not include segment profits or losses, segment assets and liabilities.

\begin{tabular}{l|c|c|c|c|c} 
& Segments & Recording & Management & Others & (in millions of $K R W$ ) \\
\hline Revenues & & 90,298 & 47,545 & 5,159 & 143,003 \\
\hline
\end{tabular}

\subsection{The Variables of Segment Disclosure Level}

Since it is difficult to measure disclosure quality due to its qualitative attributes, there is no consensus on the proxy for a firm's disclosure quality in previous literature (Lang \& Lundholm, 1993; Botosan, 1997; Heflin, Shaw, \& Wild, 2005). Botosan (1997) measures disclosure level on the basis of the amount of voluntary disclosure provided in the annual reports and Lang and Lundholm (1996) use Financial Analysts Federation (FAF) rating to capture firm's disclosure policies.

We employ two measures of segment disclosure level to examine its effects on analysts' forecast accuracy: (1) the number of segment-level line items firms disclose, and (2) whether firms disclose segment-level important accounting information. To measure the level of details in segment disclosure, we use business segment disclosure score, SEGDIS, and geographical segment disclosure score, GDIS. We calculate SEGDIS as the number of lines of accounts by each business segment reported in footnotes. Similarly, GDIS is calculated as the number of lines of accounts by each geographical segment. Since the segment disclosure quality is difficult to be estimated, these variables of segment 
disclosure levels can be viewed as reasonable measures to capture the extent to which firms release detailed segment information in their annual reports. As a proxy for the segment-level important accounting information, we use the disclosure of segment operating income (SDIS_OI).

\section{RESEARCH DESIGN}

\subsection{Data and Sample Selection}

We focus on the consolidated earnings forecasts of individual financial analysts who follow companies listed in Korean Stock Exchange in the post-IFRS period. ${ }^{2}$ Our initial sample is comprised of 11,383 forecasts over the period from 2012 to 2015. We collect sample firm's segment disclosure data from the footnotes to the financial statements. Sample period begins in 2011 which is the first year after the mandatory adoption of the IFRS in Korea. We obtain other financial data from the TS2000 database provided by Korean Listed Companies Association. Our requirements for a December year-end and no missing data for empirical analysis lead to a final sample of 11,084 forecasts observations. We winsorize all continuous variables at the top and bottom one percent levels to mitigate the effect of outliers on empirical results.

\subsection{Regression Model}

\subsubsection{The Effect of Segment Disclosure Levels on Analyst Forecast Accuracy}

Upon the introduction of IFRS, we examine the effect of the level of segment information on analysts' forecast accuracy by estimating the following regression model (1).

$$
\begin{aligned}
& A C C_{-} N I=a_{0}+a_{1} S E G D I S+a_{2} G D I S+a_{3} S I Z E+a_{4} L E V+a_{5} R O A+a_{6} L O S S \\
& +a_{7} S G W+a_{8} H O R+a_{9} A N A L+a_{10} B I G 4+a_{11} M K T+\Sigma I N D U S T R Y+\Sigma Y E A R+\varepsilon
\end{aligned}
$$

\begin{tabular}{|c|c|}
\hline ACC_NI & $\begin{array}{l}\text { : the negative of the absolute value of the analyst earnings forecast error, deflated by total } \\
\text { assets as of the beginning of the fiscal year; }\end{array}$ \\
\hline SEGDIS & : the number of disaggregated accounting information by each business segment; \\
\hline GDIS & : the number of disaggregated accounting information by each geographical segment; \\
\hline SIZE & : the natural logarithm of total assets as of the beginning of the fiscal year; \\
\hline LEV & : the total liabilities divided by total assets as of the beginning of the fiscal year; \\
\hline ROA & : net income divided by total assets; \\
\hline LOSS & : an indicator variable that equals one when net income is negative, otherwise 0 ; \\
\hline SGW & : the sales growth rate; \\
\hline HOR & $\begin{array}{l}\text { : the natural logarithm of daily periods between an analyst's forecast date and issuance date } \\
\text { of annual report; }\end{array}$ \\
\hline ANAL & : the natural logarithm of the number of analysts followings; \\
\hline BIG4 & $\begin{array}{l}\text { : an indicator variable that equals one when the firm is audited by Big } 4 \text { accounting firms, } \\
\text { otherwise } 0 \text {; }\end{array}$ \\
\hline MKT & $\begin{array}{l}\text { : an indicator variable that equals one when the firm is listed in KOSDAQ market, otherwise } \\
0 \text {; and }\end{array}$ \\
\hline ND & : industry indicator variables; and \\
\hline & ear indicator variables. \\
\hline
\end{tabular}

where

The dependent variable is earnings forecast accuracy (ACC_NI). ACC_NI is calculated as the negative value of the difference between actual net income and the first earnings forecast of individual analysts, deflated by total assets as of the beginning of the fiscal year. The main variables of interest are the number of disaggregated accounting

\footnotetext{
${ }^{2}$ The first forecast is used among earnings forecasts within the individual analyst to better capture the effect of corporate disclosure on analysts' forecasting process.
} 
information by each business segment (SEGDIS) and the number of disaggregated information by each geographical segment (GDIS). We use one-year lagged variables for disclosure levels to test whether segment information disclosed in financial statements in this year is useful for financial analysts to forecast next year earnings. We predict that the level of segment disclosure is positively related with analysts' forecast accuracy. Then, the coefficients of $\alpha_{1}$ and $\alpha_{2}$ are expected to be positive.

We control the determinants of analysts' forecast accuracy which have been documented in prior research. We include firm size (SIZE), leverage (LEV) and return on assets (ROA) as control variables. There are inconclusive results in prior research regarding the relation between firm size (SIZE) and analysts' forecast accuracy. Since disclosure levels are positively correlated with firm size, some studies provide evidence of the positive relation between analysts' forecast accuracy and firm size (Lang \& Lundholm, 1993; Bhushan 1989). On the other hand, as firm size is related with business complexity, firm size is negatively related with analysts' forecast accuracy. The leverage, LEV, tends to negatively relate to forecast accuracy. Since high-growth and high-performance firm attract greater investor interest and thus affect analysts' forecast activities (Lehavy, Li, \& Merkley, 2011), we include the sales growth rate (SGW) and the return on assets (ROA) to control for growth and firm performance. We also include controls for firms' information environment, specifically, the time from the individual analyst's forecast date to the firm's earnings announcement date (HOR) and the number of analysts following (ANAL). Since we use forecast-level dataset, the residuals can be correlated across firms. To control these correlations, we estimate regression coefficients using clustered standard errors by firm (Petersen, 2009).

\subsubsection{The Effect of Segment Disclosure Information on Analyst Forecast Accuracy}

We estimate following specification to test whether the disclosure of segment operating income information would enable analysts to make better use of financial information to forecast future earnings.

$$
\begin{aligned}
A C C_{-} N I(O I)= & a_{0}+a_{1} S D I S_{-} O I+a_{2} S I Z E+a_{3} L E V+a_{4} R O A+a_{5} L O S S+a_{6} S G W \\
& +a_{7} H O R+a_{8} A N A L+a_{9} B I G 4+a_{10} M K T+\Sigma I N D U S T R Y+\Sigma Y E A R+\varepsilon
\end{aligned}
$$

where

$$
\begin{aligned}
& \text { ACC_NI(OI) : the negative of the absolute value of the analyst earnings (operating income) forecast } \\
& \text { error, deflated by total assets of the beginning of the fiscal year; } \\
& \text { SDIS_OI indicator variable that equals one when the firm discloses segment operating income, } \\
& \text { otherwise } 0 .
\end{aligned}
$$

$\mathrm{H} 2$ predicts that the disclosure of segment operating income in the annual reports has a positive association with analysts' earnings forecasts. ACC_NI(OI) is the negative of the absolute of the analyst earnings (operating income) forecast error, deflated by total assets as of the beginning of the fiscal year. Our interest variable SDIS_OI is an indicator variable that equals one when the firm discloses segment-level information of operating income. Thus, the coefficients of $\alpha_{1}$ are expected to be positive.

\subsubsection{The Effect of Segment Disclosure Information on Multi-Segment Firms}

To examine the beneficial effects of segment disclosure quality on analysts' forecast accuracy for firms with greater complexity, we use a following regression model:

$$
\begin{aligned}
& A C C_{N I}=a_{0}+a_{1} \text { SEGNUM }+a_{2} \text { GNUM }+a_{3} \text { SEGDIS }+a_{4} \text { GDIS }+a_{5} \text { SEGNUMDIS } \\
& +a_{6} G N U M D I S+a_{7} \text { SIZE }+a_{8} \text { LEV }+a_{9} \text { ROA }+a_{10} \text { LOSS }++a_{11} \text { SGW }+a_{12} H O R \\
& +a_{13} \text { ANAL }+a_{14} \text { BIG }+a_{15} \text { MKT }+\Sigma I N D U S T R Y+\Sigma Y E A R+\varepsilon
\end{aligned}
$$


Where

$\begin{array}{ll}\text { SEGNUM } & : \text { the reported number of business segments; } \\ \text { GNUM } & : \text { the reported number of geographical segments; } \\ \text { SEGDIS } & : \text { the number of disaggregated accounting information by each business segment; } \\ \text { GDIS } & : \text { the number of disaggregated accounting information by each geographical segment; } \\ \text { SEGNUMDIS } & : \text { the interaction term of variables of SEGNUM and SEGDIS; and } \\ \text { GNUMDIS } & : \text { the interaction term of variables of GNUM and GDIS. }\end{array}$

We perform an analysis to control for the firm's organizational structure and complexity of their business activities. We include a measure of operational complexity in analysis, defined in terms of its lines of business and/or geographical segments. Firms with more lines of business and/or geographical segments are viewed as more complex and diversified. The proxy for operating complexity is calculated as the number of the reported business segment (SEGNUM) and geographical segment (GNUM).

\section{RESULTS}

\subsection{Descriptive Statistics}

Table 1 provides descriptive statistics for the variables used in our regression analyses. The mean values of the number of business segment (SEGNUM) and geographical segment (GNUM) are 3.17 and 2.8, respectively. The SEGNUM ranges from 0 to 12, and the GNUM ranges from 0 to 16 . Korean firms are generally considered to diversify their business and/or geographical segments, but the degree of diversification disclosed in the annual report varies widely among firms. Moreover, the number of disaggregated financial information for each business segment (SEGDIS) and for geographical segment (GDIS) ranges from 0 to 19 and from 0 to 14, respectively. It implies that principle-based IFRS which does not provide universal reporting format may lead to a wide variation of the extent of disaggregated information among firms. On average, $66 \%$ of firms disclose segment-level operating income information (SDIS_OI).

Table1. Descriptive statistics

\begin{tabular}{l|c|c|c|c|c|c|c}
\hline \multicolumn{1}{c}{ Variables } & Mean & Std dev & Min & $\mathbf{1}^{\text {st }}$ quartile & Median & $3^{\text {rd }}$ quartile & Max \\
\hline ACC_NI & -0.330 & 0.650 & -10.262 & -0.348 & -0.162 & -0.067 & 0.000 \\
\hline ACC_OI & -0.868 & 1.036 & -17.164 & -1.136 & -0.593 & -0.311 & 0.000 \\
\hline SEGNUM & 3.172 & 1.861 & 0 & 2 & 3 & 4 & 12 \\
\hline GNUM & 2.799 & 2.129 & 0 & 1 & 3 & 4 & 16 \\
\hline SEGDIS & 4.623 & 3.907 & 0 & 1 & 4 & 7 & 19 \\
\hline GDIS & 1.882 & 1.582 & 0 & 1 & 2 & 2 & 14 \\
\hline SDIS_OI & 0.660 & 0.474 & 0 & 0 & 1 & 1 & 1 \\
\hline SDIS_NI & 0.325 & 0.468 & 0 & 0 & 0 & 1 & 1 \\
\hline SIZE & 22.004 & 1.840 & 17.297 & 20.608 & 22.245 & 23.289 & 26.163 \\
\hline LEV & 0.491 & 0.185 & 0.045 & 0.351 & 0.521 & 0.629 & 0.922 \\
\hline ROA & 0.055 & 0.077 & -0.428 & 0.015 & 0.045 & 0.087 & 0.850 \\
\hline LOSS & 0.128 & 0.334 & 0 & 0 & 0 & 0 & 1 \\
\hline SGW & 0.133 & 0.527 & -0.837 & -0.008 & 0.069 & 0.171 & 10.650 \\
\hline HOR & 5.517 & 0.609 & 0 & 5.442 & 5.784 & 5.858 & 5.903 \\
\hline ANAL & 4.611 & 1.213 & 0 & 4.060 & 4.970 & 5.468 & 6.248 \\
\hline BIG4 & 0.907 & 0.290 & 0 & 1 & 1 & 1 & 1 \\
\hline MKT & 0.204 & 0.403 & 0 & 0 & 0 & 0 & 1 \\
\hline
\end{tabular}

Note: ACC_NI (OI) is the negative of the absolute value of the analyst earnings (operating income) forecast error, deflated by total assets as of the beginning of the fiscal year. SEGNUM is the reported number of business segment. SEGDIS is the number of desegregated accounting information by each business segment. SDIS_OI (NI) is an indicator variable that equals one when the firm discloses segment operating income (net income), otherwise 0. GNUM is the reported number of geographical segments. GDIS is the number of desegregated accounting information by each geographical segment. SIZE is the natural logarithm of total assets. LEV is the total liabilities divided by total assets as of the beginning of the fiscal year. ROA is calculated as net income divided by total assets. LOSS is an indicator variable that equals one when net income is negative, otherwise 0 . SGW is the sales growth rate. HOR is the natural logarithm of daily periods between analyst's forecast date and issuance date of annual report. ANAL is the natural logarithm of the number of analysts following. Big4 is an indicator variable that equals one when the firm is audited by Big 4 accounting firms, otherwise 0 . MKT is an indicator variable that equals one when the firm is listed in KOSDAQ market, otherwise 0 . The signs of *,**, and $* * *$ represent the significance of $10 \%, 5 \%$, and $1 \%$, respectively. 
Table 2 displays Pearson correlation coefficients for the main variables. We find that the measures of segment disclosure levels, SEGDIS and GDIS have positive correlation with analysts' earnings forecast accuracy. The variables for the disclosure of important earnings components by segment, SDIS_OI, is also positively correlated with analysts' earnings forecast accuracy. The positive relation between the level of information in segment disclosure and analysts' forecast accuracy provides preliminary evidence that disaggregated financial information by each segment is useful for analysts to forecast future consolidated performance of the firm.

Table 2. Pearson correlations

\begin{tabular}{|c|c|c|c|c|c|c|c|c|}
\hline Variables & (1) & (2) & (3) & (4) & (5) & (6) & (7) & (8) \\
\hline \multicolumn{9}{|l|}{ (1) ACC_NI } \\
\hline \multirow{2}{*}{ (2) ACC_OI } & 0.22 & & & & & & & \\
\hline & $(0.00)$ & & & & & & & \\
\hline \multirow{2}{*}{ (3) SEGNUM } & 0.06 & 0.20 & & & & & & \\
\hline & $(0.00)$ & $(0.00)$ & & & & & & \\
\hline \multirow{2}{*}{ (4) GNUM } & 0.07 & 0.06 & 0.10 & & & & & \\
\hline & $(0.00)$ & $(0.00)$ & $(0.00)$ & & & & & \\
\hline \multirow{2}{*}{ (5) SEGDIS } & 0.12 & 0.20 & 0.37 & 0.14 & & & & \\
\hline & $(0.00)$ & $(0.00)$ & $(0.00)$ & $(0.00)$ & & & & \\
\hline \multirow{2}{*}{ (6) GDIS } & 0.02 & 0.08 & 0.13 & 0.23 & 0.22 & & & \\
\hline & $(0.90)$ & $(0.00)$ & $(0.00)$ & $(0.00)$ & $(0.00)$ & & & \\
\hline \multirow{2}{*}{ (7) SDIS_OI } & 0.15 & 0.24 & 0.41 & 0.14 & 0.58 & 0.16 & & \\
\hline & $(0.00)$ & $(0.00)$ & $(0.00)$ & $(0.00)$ & $(0.00)$ & $(0.00)$ & & \\
\hline \multirow{2}{*}{ (8) SDIS_NI } & 0.06 & 0.15 & 0.32 & -0.01 & 0.58 & 0.14 & 0.23 & \\
\hline & $(0.00)$ & $(0.00)$ & $(0.00)$ & $(0.17)$ & $(0.00)$ & $(0.00)$ & $(0.00)$ & \\
\hline \multirow{2}{*}{ (9) SIZE } & 0.17 & 0.33 & 0.30 & 0.26 & 0.27 & 0.19 & 0.37 & 0.12 \\
\hline & $(0.00)$ & $(0.00)$ & $(0.00)$ & $(0.00)$ & $(0.00)$ & $(0.00)$ & $(0.00)$ & $(0.00)$ \\
\hline \multirow{2}{*}{ (10) LEV } & 0.12 & 0.38 & 0.21 & 0.05 & 0.15 & 0.10 & 0.17 & 0.12 \\
\hline & $(0.00)$ & $(0.00)$ & $(0.00)$ & $(0.00)$ & $(0.00)$ & $(0.00)$ & $(0.00)$ & $(0.00)$ \\
\hline \multirow{2}{*}{ (11) ROA } & -0.10 & -0.41 & -0.15 & -0.05 & -0.15 & -0.06 & -0.17 & -0.09 \\
\hline & $(0.00)$ & $(0.00)$ & $(0.00)$ & $(0.01)$ & $(0.00)$ & $(0.00)$ & $(0.00)$ & $(0.00)$ \\
\hline \multirow{2}{*}{ (12) LOSS } & 0.02 & 0.19 & 0.10 & 0.05 & 0.11 & 0.07 & 0.10 & 0.03 \\
\hline & $(0.10)$ & $(0.11)$ & $(0.00)$ & $(0.00)$ & $(0.00)$ & $(0.00)$ & $(0.01)$ & $(0.00)$ \\
\hline \multirow{2}{*}{ (13) SGW } & -0.05 & -0.16 & -0.00 & -0.08 & -0.05 & -0.07 & -0.01 & -0.03 \\
\hline & $(0.00)$ & $(0.00)$ & $(0.71)$ & $(0.00)$ & $(0.00)$ & $(0.00)$ & $(0.25)$ & $(0.01)$ \\
\hline \multirow{2}{*}{ (14) HOR } & -0.13 & -0.01 & 0.05 & 0.07 & 0.06 & 0.05 & 0.06 & 0.04 \\
\hline & $(0.00)$ & $(0.60)$ & $(0.00)$ & $(0.00)$ & $(0.00)$ & $(0.00)$ & $(0.00)$ & $(0.00)$ \\
\hline \multirow{2}{*}{ (15) ANAL } & 0.04 & 0.05 & 0.12 & 0.23 & 0.23 & 0.18 & 0.15 & 0.08 \\
\hline & $(0.00)$ & $(0.00)$ & $(0.00)$ & $(0.00)$ & $(0.00)$ & $(0.00)$ & $(0.00)$ & $(0.00)$ \\
\hline \multirow{2}{*}{ (16) BIG4 } & 0.03 & 0.12 & 0.14 & 0.16 & 0.16 & 0.20 & 0.21 & -0.02 \\
\hline & $(0.00)$ & $(0.00)$ & $(0.00)$ & $(0.00)$ & $(0.96)$ & $(0.00)$ & $(0.00)$ & $(0.01)$ \\
\hline \multirow{2}{*}{ (17) MKT } & 0.15 & 0.30 & 0.17 & 0.20 & 0.20 & 0.34 & 0.24 & 0.21 \\
\hline & $(0.00)$ & $(0.00)$ & $(0.00)$ & $(0.00)$ & $(0.00)$ & $(0.00)$ & $(0.00)$ & $(0.00)$ \\
\hline
\end{tabular}

(Table 2 continued on next page) 
(Table 2 continued)

\begin{tabular}{|c|c|c|c|c|c|c|c|c|}
\hline Variables & (9) & (10) & (11) & (12) & (13) & (14) & (15) & (16) \\
\hline \multirow{2}{*}{ (10) LEV } & 0.40 & & & & & & & \\
\hline & $(0.00)$ & & & & & & & \\
\hline \multirow{2}{*}{ (11) ROA } & -0.19 & -0.43 & & & & & & \\
\hline & $(0.01)$ & $(0.00)$ & & & & & & \\
\hline \multirow{2}{*}{ (12) LOSS } & 0.14 & 0.33 & -0.42 & & & & & \\
\hline & $(0.01)$ & $(0.00)$ & $(0.00)$ & & & & & \\
\hline \multirow{2}{*}{ (13) SGW } & -0.07 & -0.03 & 0.07 & -0.10 & & & & \\
\hline & $(0.00)$ & $(0.01)$ & $(0.00)$ & $(0.00)$ & & & & \\
\hline \multirow{2}{*}{ (14) HOR } & 0.24 & 0.06 & -0.00 & 0.02 & -0.02 & & & \\
\hline & $(0.00)$ & $(0.00)$ & $(0.64)$ & $(0.01)$ & $(0.05)$ & & & \\
\hline \multirow{2}{*}{ (15) ANAL } & 0.69 & 0.10 & 0.07 & 0.01 & -0.02 & 0.29 & & \\
\hline & $(0.00)$ & $(0.00)$ & $(0.00)$ & $(0.54)$ & $(0.02)$ & $(0.00)$ & & \\
\hline \multirow{2}{*}{ (16) BIG4 } & 0.39 & 0.10 & -0.04 & 0.03 & -0.02 & 0.10 & 0.35 & \\
\hline & $(0.00)$ & $(0.00)$ & $(0.00)$ & $(0.00)$ & $(0.07)$ & $(0.00)$ & $(0.00)$ & \\
\hline \multirow{2}{*}{ (17) MKT } & 0.63 & 0.37 & -0.14 & 0.12 & -0.13 & 0.16 & 0.44 & 0.30 \\
\hline & $(0.00)$ & $(0.00)$ & $(0.00)$ & $(0.00)$ & $(0.00)$ & $(0.00)$ & $(0.00)$ & $(0.00)$ \\
\hline
\end{tabular}

Note: Numbers in parentheses are p-values. Variable definitions are given in Table 1.

\subsection{Regression Results}

\subsubsection{The Effect of Voluntary Segment Disclosure Level on Analysts' Forecast Accuracy}

Table 3 provides the empirical results of Eq. (1). Column (1) shows estimation results for the effect of the level of disaggregated financial information by business line (SEGDIS) on analysts' forecast accuracy (ACC NI) after controlling for firm and forecast characteristics. We find that SEGDIS is positively associated with ACC_NI at the $1 \%$ level (t-statistic of 3.00). Consistent with Hypothesis 1, these results suggest that analysts can forecast consolidated earnings more accurately for firms with more detailed data provisions with a respect to segment in their financial statements than firms with less information provisions.

Column (2) shows that the level of disaggregated information by geographical segment is positively related to analysts' forecast accuracy (ACC_NI) at the 10\% level (t-statistic of 1.87). This result is consistent with Hypothesis 1 , which states that analysts predict consolidated earnings more accurately for firms which provide greater detailed financial information on each geographical segment.

In column (3), we confirm that these results hold after controlling for the levels of segment-level information both for business lines (SEGDIS) and for geographical departments (GDIS). To summarize, table 3 shows that the accuracy of analyst's consolidated earnings forecast improves as the firm discloses more detailed segment-level information by business and/or geographical segments. 
Table 3. The Effects of Segment Disclosure Levels on Analysts' Forecast Accuracy

\begin{tabular}{|c|c|c|c|c|c|c|}
\hline \multirow{2}{*}{ Variables } & \multicolumn{2}{|c|}{ Column (1) } & \multicolumn{2}{|c|}{ Column (2) } & \multicolumn{2}{|c|}{ Column (3) } \\
\hline & Coefficients & t-value & Coefficients & t-value & Coefficients & t-value \\
\hline Intercept & $0.678^{* * *}$ & 6.00 & $0.668^{* * *}$ & 5.87 & $0.679^{* * *}$ & 6.00 \\
\hline SEGDIS & $0.003^{* * *}$ & 3.00 & & & $0.003^{* *}$ & 2.71 \\
\hline GDIS & & & $0.007^{*}$ & 1.87 & $0.006^{*}$ & 1.65 \\
\hline SIZE & $0.011^{* *}$ & 2.26 & $0.012^{* *}$ & 2.41 & $0.011^{* *}$ & 2.29 \\
\hline LEV & -0.029 & -0.79 & -0.035 & -0.94 & -0.031 & -0.85 \\
\hline $\mathrm{ROA}$ & -0.142 & -1.48 & -0.143 & -1.49 & -0.143 & -1.49 \\
\hline LOSS & 0.002 & 0.13 & 0.003 & 0.20 & 0.001 & 0.04 \\
\hline SGW & $-0.039^{* * *}$ & -4.63 & $-0.038^{* * *}$ & -4.54 & $-0.038^{* * * *}$ & -4.50 \\
\hline HOR & $-0.185^{* * *}$ & -23.45 & $-0.185^{* * *}$ & -23.46 & $-0.185^{* * *}$ & -23.46 \\
\hline ANAL & 0.003 & 0.27 & 0.002 & 0.13 & 0.002 & 0.13 \\
\hline BIG4 & -0.016 & -0.70 & -0.021 & -0.88 & -0.022 & -0.90 \\
\hline MKT & $-0.036^{* * *}$ & -8.37 & $-0.036^{* * *}$ & -8.45 & $-0.036^{* * * *}$ & -8.50 \\
\hline INDUSTRY & \multicolumn{2}{|c|}{ Control } & \multicolumn{2}{|c|}{ Control } & \multicolumn{2}{|c|}{ Control } \\
\hline YEAR & \multicolumn{2}{|c|}{ Control } & \multicolumn{2}{|c|}{ Control } & \multicolumn{2}{|c|}{ Control } \\
\hline Obs. Numbers & \multicolumn{2}{|c|}{11,084} & \multicolumn{2}{|c|}{11,084} & \multicolumn{2}{|c|}{11,084} \\
\hline Adj. R-square & \multicolumn{2}{|c|}{$24.15 \%$} & \multicolumn{2}{|c|}{$24.53 \%$} & \multicolumn{2}{|c|}{$24.16 \%$} \\
\hline F-Value & \multicolumn{2}{|c|}{64.01} & \multicolumn{2}{|c|}{64.00} & \multicolumn{2}{|c|}{62.93} \\
\hline
\end{tabular}

Note: This table shows the empirical results of three regressions of the dependent variable (ACC_NI) on segment disclosure levels. The main dependent variable of ACC NI is calculated by the negative of the absolute value of the analyst earnings forecast error, deflated by total assets as of the beginning of the fiscal year. SEGDIS is the number of desegregated accounting information by each business segment. GDIS is the number of desegregated accounting information by each geographical segment. SIZE is the natural logarithm of total assets. LEV is the total liabilities divided by total assets as of the beginning of the fiscal year. ROA is calculated as net income divided by total assets. LOSS is an indicator variable that equals one when net income is negative, otherwise 0 . SGW is the sales growth rate. HOR is the natural logarithm of daily periods between analyst's forecast date and issuance date of annual report. ANAL is the natural logarithm of the number of analyst followings. Big4 is an indicator variable that equals one when the firm is audited by Big 4 accounting firms, otherwise 0 . MKT is an indicator variable that equals one when the firm is listed in KOSDAQ market, otherwise 0 . The signs of ${ }^{* *}$, and *** represent the significance of $10 \%, 5 \%$, and $1 \%$, respectively (using twotailed test). Standard errors are clustered by firm (Petersen 2009).

\subsubsection{The Effect of Segment Information on Analysts' Forecast Accuracy}

Table 4 reports the regression results of whether analysts exhibit better earnings forecasting performance when firms disclose significant accounting numbers with a respect to their segments (H2). In column (1), the results show that an indicator variable for firms disclose segmented information of operating income (SDIS_OI) is positively associated with the accuracy of analysts' earnings forecasts (ACC_NI) at the $1 \%$ level (t-statistic of 2.71 ).

Moreover, column (2) shows that the coefficient estimate on SDIS_OI is positive and significant for operating income forecast accuracy (t-statistic of 5.42), suggesting that the disclosure of operating income by each segments results in the more accurate earnings forecasts via more accurate forecasting process of operating performance. Thus, our results show that firm-provided segment-level operating income information is useful for analysts to predict accurately future operating income of the firm.

Taken together, the regression results of $\mathrm{H} 1$ and $\mathrm{H} 2$ indicate that both the number of line items and the types of accounting information for each reportable segment improve financial analysts' forecasting performance of consolidated earnings. These results imply that, despite the concern about managerial discretion in segment disclosure, firm-provided detailed information for each segment will help financial analysts to forecast consolidated performance of the firm. 
Table 4. Segment Disclosure of Operating income and Forecast Accuracy

\begin{tabular}{|c|c|c|c|c|}
\hline \multirow{3}{*}{ Variables } & \multirow{2}{*}{\multicolumn{2}{|c|}{$\begin{array}{c}\text { Dependent variable: } \\
\text { ACC_NI } \\
\text { Column (1) }\end{array}$}} & \multirow{2}{*}{\multicolumn{2}{|c|}{$\begin{array}{c}\text { Dependent variable: } \\
\text { ACC_OI } \\
\text { Column (2) }\end{array}$}} \\
\hline & & & & \\
\hline & Coefficients & t-value & Coefficients & t-value \\
\hline Intercept & $0.288^{* * *}$ & 2.6 & $-2.286^{* * *}$ & -10.67 \\
\hline SDIS_OI & $0.031^{* * *}$ & 2.71 & $0.085^{* * *}$ & 5.42 \\
\hline SIZE & $-0.017^{* * *}$ & 5.54 & $0.078^{* * *}$ & 10.66 \\
\hline LEV & -0.109 & -0.47 & $0.510^{* * *}$ & 7.86 \\
\hline ROA & 0.007 & -1.12 & $-3.726^{* * *}$ & -9.53 \\
\hline LOSS & -0.048 & 0.54 & 0.005 & 0.17 \\
\hline SGW & $-0.183^{* * *}$ & -5.74 & $-0.305^{* * *}$ & -5.69 \\
\hline HOR & $0.007^{* * *}$ & -23.22 & $-0.070^{* * *}$ & -4.74 \\
\hline ANAL & -0.014 & 0.61 & $-0.164^{* * *}$ & -10.08 \\
\hline BIG4 & 0.011 & -0.6 & $0.162^{* * *}$ & 6.60 \\
\hline MKT & 0.288 & 0.78 & $-0.029^{* * *}$ & -3.95 \\
\hline INDUSTRY & \multicolumn{2}{|c|}{ Control } & \multicolumn{2}{|c|}{ Control } \\
\hline YEAR & \multicolumn{2}{|c|}{ Control } & \multicolumn{2}{|c|}{ Control } \\
\hline Obs. Numbers & \multicolumn{2}{|c|}{11,084} & \multicolumn{2}{|c|}{11,084} \\
\hline Adj. R-square & \multicolumn{2}{|c|}{$23.87 \%$} & \multicolumn{2}{|c|}{$43.55 \%$} \\
\hline F-Value & \multicolumn{2}{|c|}{63.05} & \multicolumn{2}{|c|}{145.44} \\
\hline
\end{tabular}

Note: This table shows the results of regressions of analysts' forecast accuracy on the segmented disclosure of operating (net) income. ACC_NI (OI) is the negative of the absolute value of the analyst earnings (operating income) forecast error, deflated by total assets as of the beginning of the fiscal year. SDIS OI is an indicator variable that equals one when the firm discloses segmented information of operating income, otherwise 0. The signs of *, **, and *** represent the significance of $10 \%, 5 \%$, and $1 \%$, respectively (using two-tailed test). Standard errors are clustered by firm (Petersen 2009).

\subsubsection{The Beneficial Effect of Segmented Information}

Table 5 reports the results of whether the beneficial effect of segment information on analysts' forecasting performance is greater for firms with multiple segments. In column (1), we find that the association between levels of firm's disclosure of segmented information and analysts' forecast accuracy holds constant after controlling firm's operational and geographical business complexity.

In column (2), we include GNUM and its interaction with GDIS and SEGNUM its interaction with SEGDIS. If analysts have difficulties in forecasting earnings for more complex firms, we predict that the beneficial effect of segment reporting on forecasting performance will be improved as the firms' operational complexity increases. Consistent with our prediction, the coefficient estimate of interaction term between the business complexity and the level of segment information (SEGNUMDIS) is significantly positive at the $1 \%$ level (t-statistic of 2.28). 
Table 5. The Effects of Segment Disclosure Levels on Forecasts for Diversified Firms

\begin{tabular}{|c|c|c|c|c|}
\hline \multirow{2}{*}{ Variables } & \multicolumn{2}{|c|}{ Column (1) } & \multicolumn{2}{|c|}{ Column (2) } \\
\hline & Coefficients & t-value & Coefficients & t-value \\
\hline Intercept & 0.095 & 0.97 & 0.132 & 1.32 \\
\hline SEGDIS & $0.005^{* * *}$ & 4.48 & -0.001 & -0.20 \\
\hline GDIS & $0.008^{* *}$ & 2.11 & $0.014^{* * *}$ & 2.66 \\
\hline SEGNUM & $-0.006^{* *}$ & -2.10 & $-0.012^{* * *}$ & -2.88 \\
\hline GNUM & $-0.024^{* * *}$ & -4.21 & $-0.020^{* * *}$ & -2.58 \\
\hline SEGNUMDIS & & & $0.002^{* *}$ & 2.28 \\
\hline GNUMDIS & & & -0.003 & -1.50 \\
\hline SIZE & $0.040^{* * *}$ & 8.73 & $0.039^{* * *}$ & 8.15 \\
\hline LEV & -0.054 & -1.54 & -0.055 & -1.56 \\
\hline $\mathrm{ROA}$ & -0.136 & -1.46 & -0.131 & -1.41 \\
\hline LOSS & 0.001 & 0.06 & -0.003 & -0.22 \\
\hline SGW & $-0.053^{* * *}$ & -6.07 & $-0.052^{* * *}$ & -5.78 \\
\hline HOR & $-0.184^{* * *}$ & -23.27 & $-0.184^{* * *}$ & -23.27 \\
\hline ANAL & 0.004 & 0.34 & 0.005 & 0.41 \\
\hline BIG4 & -0.017 & -0.72 & -0.020 & -0.81 \\
\hline MKT & 0.004 & 0.22 & 0.014 & 0.80 \\
\hline INDUSTRY & \multicolumn{2}{|c|}{ Control } & \multicolumn{2}{|c|}{ Control } \\
\hline YEAR & \multicolumn{2}{|c|}{ Control } & \multicolumn{2}{|c|}{ Control } \\
\hline Obs. Numbers & \multicolumn{2}{|c|}{11,084} & \multicolumn{2}{|c|}{11,084} \\
\hline Adj. R-square & \multicolumn{2}{|c|}{$24.23 \%$} & \multicolumn{2}{|c|}{$24.25 \%$} \\
\hline F-Value & \multicolumn{2}{|c|}{61.08} & \multicolumn{2}{|c|}{59.16} \\
\hline
\end{tabular}

Note: This table shows the results of analysis after controlling for a firm's segment numbers. SEGNUM is the number of business segment, and GNUM is the number of geographical segment reported in an annual report. SEGNUMDIS is the interaction term of variables of SEGNUM and SEGDIS. GNUMDIS is the interaction term of variables of GNUM and GDIS. The signs of *, **, and *** represent the significance of $10 \%, 5 \%$, and $1 \%$, respectively (using two-tailed test). Standard errors are clustered by firm (Petersen 2009).

\section{CONCLUSIONS}

We examine the impact of the segment disclosure level in an annual report on analysts' forecast accuracy in the context of principle-based IFRS adoption. Since the adoption of IFRS results in a wide variation of disclosure levels among companies, it brings more divergences in discretionary disclosures in annual reports among companies, including segment information disclosures.

In this study, we estimate "segment disclosure level" under IFRS 8 'Operating Segments' and provide evidence that firms which release more disaggregated information of each business segment and/or geographical segment could potentially improve the usefulness of financial information to financial analysts who are sophisticated users of financial reporting. Specifically, we find that the accuracy of analysts' earnings forecasts is positively associated with the level of segment disclosure in the annual report. We also provide evidence that the disclosure of operating income information by each business segment is critical to improve the accuracy of analysts' forecasts. Moreover, we show that the positive relation between segment disclosure levels and analysts forecast accuracy becomes stronger when a firm has more numbers of operating segment, suggesting that the usefulness of firm-provided disaggregated information to external users is heightened for firms with greater operational complexity. Overall, the results are consistent with the view that the quality of information that the firm discloses in its annual report increases the accuracy of financial analysts' earnings forecasts by reducing information asymmetry between the firm and external users.

We contribute literature on corporate mandatory disclosure focusing on the role of segment disclosure information in the annual report to external users. For five years after introducing IFRS in Korea, many studies have conducted analyses if the costs and benefits of IFRS adoption but have provided inconclusive results for the effect of IFRS adoption. We attempt to provide an explanation for differential effect of IFRS adoption on financial reporting. 
Our empirical results add some evidence on the importance of disclosure quality to analysts' forecasting performance under principle-based IFRS where the extent of information provided by the firm differs significantly. These issues might be of interest for regulators, scholars, and various other parties to examine differential effects of IFRS.

\section{AUTHOR BIOGRAPHIES}

Kyongsun Heo is an assistant professor of Global Business School, Kangnam University. Her research interests include corporate pension plans, financial market reaction and corporate valuations.

E-mail: kyongsun.heo@gmail.com

Seoyoung Doo is a researcher of the Korean Institute of Certified Public Accountants. Her research interests include earnings management, financial and tax disclosures, and corporate governance. E-mail: seoyoung.doo@gmail.com

\section{REFERENCES}

Baginski, S., \& Hassell, J. (1990). The market interpretation of management earnings forecasts as a predictor of subsequent financial analyst forecast revision. The Accounting Review, 65(1), 175-190.

Baldwin, B. (1984). Segment earnings disclosure and the ability of security analysts to forecast earnings per share. The Accounting Review, 59(3), 376-389.

Berger, P., \& Hann R. (2003). The impact of SFAS No. 131 on information and monitoring. Journal of Accounting Research, 41(2), 163-223.

Berger, P., \& Hann, R. (2007). Segment profitability and the proprietary and agency costs of disclosure. The Accounting Review, 82(4), 869-906.

Bhushan, R. (1989). Firm characteristics and analyst following. Journal of Accounting \& Economics, 11(2), 255-274.

Bonsall IV, S. B. \& Miller, B. P. (2014). The impact of financial disclosure complexity on bond rating agency disagreement and the cost of debt capital. Working paper.

Botosan, C. A. (1997). Disclosure level and the cost of equity capital. The Accounting Review, 72(3), 323-349.

Chun, S., Lee, A., Kim, M., Kim, S., \& Cho, E. (2013). Perception and usage behavior of financial analyst on public and private information. Korean Accounting Journal, 22(3), 253-295. [Printed in Korean]

Collins, D. W. (1976). Predicting earnings with sub-entity data: Some further evidence. Journal of Accounting Research, 14(1), 163-177.

Duchin, R. (2010). Cash holdings and corporate diversification. Journal of Finance, 65(3), 955-992.

Ettredge, M., Kwon, S., Smith, D., \& Zarowin, R. (2005). The Impat of SFAS No. 131 Business Segment Data on the market's ability to anticipate future earnings. The Accounting Review, 80(3), 773-804.

Heflin, F., Shaw, K., \& Wild, J. (2005). Disclosure policy and market liquidity: Impact of depth quotes and order sizes. Contemporary Accounting Research, 22(4), 689-731.

Hope, O., \& Thomas, W. B. (2008). Managerial empire building and firm disclosure. Journal of Accounting Research, 46(3), 591-626.

Jennings, R. (1987). Unsystematic security price movements, managerial earnings forecasts, and revisions in consensus analyst earnings forecasts. Journal of Accounting Research, 25(1), 90-110.

Kinney. W. R. (1971). Predicting earnings: Entity versus subentity data. Journal of Accounting Research, 9(1), 127-136.

Kochanek. R. F. (1974). Segmental financial disclosure by diversified firms and security prices. The Accounting Review, 49(2), 245-258.

Lang, M. C., \& Lundholm, R. J. (1993). Cross-sectional determinants of analyst ratings of corporate disclosures. Journal of Accounting Research, 31(2), 246-271.

Lang, M. C., \& Lundholm, R. J. (1996). Corporate disclosure policy and analyst behavior. The Accounting Review, 71(4), 467492.

Lehavy, R., Li, F., \& Merkley, K. (2011). The effect of annual report readability on analyst following and the properties of their earnings forecasts. The Accounting Review, 86(3), 1087-1115.

Nichols, N. B., Street, D. L., \& Tarca, A. (2013). The impact of segment reporting under the IFRS 8 and SFAS 131 management approach: A research review. Journal of International Financial Management \& Accounting, 24(3), 261-312.

Ohlson, J. A. (1999). On transitory earnings. Review of Accounting Studies, 4, 145-162. 
Petersen, M. A. (2009) Estimating standard errors in finance panel data sets: Comparing approaches. Review of Financial Studies, $22(1), 435-480$.

Rajan, R., Servaes, H., \& Zingales, L. (2000). The cost of diversity: The diversification discount and inefficient investment. Journal of Finance, 55(1), 35-80.

Shin, H. H., \& Stulz, R. (1998). Are internal capital markets efficient? Quarterly Journal of Economics, 113(2), 531-552. 


\section{NOTES}

